\title{
Foreign Currency \\ Risk Management Practices in U.S. Multinationals
}

Dr. Stephen D. Makar, Accounting, University of Wisconsin Oshkosh Dr. Stephen P. Huffman, Finance, University of Wisconsin Oshkosh

\begin{abstract}
Today's multinational companies face potentially significant economic exposure to changing exchange rates. One way to manage such currency risk is through the use of foreign exchange derivatives. This paper examines how foreign exchange derivatives are used by U.S. multinationals. Recent studies report that the use of foreign exchange derivatives varies across U.S. multinationals and may depend on a variety of influences, including industry membership. We develop a model to explain these variations in the amounts of derivatives used in terms of differences in foreign currency exposure. The results are consistent with our expectations. In particular, the evidence pertaining to a sample of 64 U.S. multinationals for the 1990-1994 period indicates that the notional amounts of foreign exchange derivatives are positively associated with the degree of foreign involvement, which proxies foreign currency exposure. Moreover, the results are not sensitive to industry membership or other interfirm differences. The findings of this paper are important because they contribute to a better understanding of the foreign currency risk management practices in U.S. multinationals.
\end{abstract}

\section{Introduction}

n he business strategy of U.S. companies is becoming increasingly global. In 1995, for example, exports of U.S. goods rose 14.6 percent from 1994 to $\$ 575.9$ billion, while imports reached a record $\$ 749.4$ billion. In addition, U.S. multinational companies (MNCs) are heavily involved in global business operations through investments in foreign subsidiaries, branches and joint ventures. For example, the 1995 IBM Annual Report details that nearly two thirds of the company's $\$ 71.9$ billion in consolidated sales came from operations located in foreign countries.

By going global, U.S. based MNCs are exposed to risks associated with changes in for- eign currency exchange rates. General Electric (GE), for example, is a U.S. based company that deals with dozens of currencies. In challenging its executives to think globally, GE emphasizes that the "management of currency risk goes hand-in-hand with the globalization of today's business environment" (Whitaker 1994, p. 247). One way in which U.S. MNCs reduce or hedge their currency risk is through the use of foreign exchange derivatives.

This paper examines how U.S. MNCs use foreign exchange derivatives (FXD). While recent derivative losses have stirred public debate, both critics and advocates invariably cite hedging as the best use of these financial con- 
tracts (Pare 1994). ${ }^{1} \quad$ Prior research, however, indicates that the use of FXD (as measured by notional principal amounts) varies substantially across U.S. MNCs, and may depend on a variety of influences, including industry membership. This paper provides insight into these multidimensional aspects of managing currency risk. The Financial Accounting Standards Board has emphasized that such research on issues currently under deliberation is critical to the standard setting process (Beresford and Johnson 1995).

\section{Background}

\section{Foreign Currency Exposure}

Companies having foreign operations and/or international trade transactions denominated in a foreign currency are directly exposed to losses associated with changing exchange rates. $^{2}$ For example, suppose that a U.S. MNC exports car parts to a Mexican company for three million pesos. Terms of the sale require that the U.S. company is paid in pesos, 60 days from the invoice date. If the prevailing exchange rate is three pesos per dollar, the sale will generate one million U.S. dollars. Assuming product costs of $\$ 750,000$, the sale will provide the U.S. exporter a profit of $\$ 250,000$. After 60 days, however, the company is shocked to learn that the exchange rate is no longer three pesos per dollar, but five pesos per dollar (a decline in the value of the peso similar to the 1994 devaluation). Thus, the company only receives $\$ 600,000$ from its peso-denominated accounts receivable and loses $\$ 150,000$ on the sale.

In contrast to a peso-devaluation scenario, the export transaction could have occurred when the peso is strengthening. In this scenario, the U.S. exporter would experience an economic gain, ceteris paribus. Similarly, the currency risk faced by companies with operations in foreign countries pertains to the U.S. MNC's pesodenominated foreign investment (i.e., the net assets of the foreign operations). Thus like the U.S. exporter, such companies are exposed to foreign exchange losses (gains) when the peso weakens (strengthens) relative to the U.S. dollar.
For example, the dollar value of a self-contained Mexican subsidiary's profits would decrease with a peso devaluation, ceteris paribus. ${ }^{3}$

Recently, researchers have relied on such insight into foreign exchange gains and losses as a theoretical basis for examining the impact of exchange rate changes on firm value. Beginning with Jorion (1990), these studies have provided evidence that a company's total foreign currency exposure (defined as the sensitivity of firm value to random changes in exchange rates) is positively correlated with its degree of foreign involvement. ${ }^{4}$ That is, the higher the relative level of foreign sales (relative to the company's size), the greater the response of stock returns to unanticipated changes in exchange rates. We employ this foreign-involvement proxy of a company's total currency exposure to examine U.S. MNC's use of derivatives.

\section{Foreign Currency Hedging Practices}

Hedging is a defensive strategy that reduces or eliminates the risks associated with exchange rate changes and other adverse price movements (Financial Instruments Task Force 1994). One way in which U.S. MNCs hedge their foreign currency risk is through the use of derivatives. Derivatives are financial instruments that derive their value from an underlying variable such as exchange rates, interest rates or commodity prices. Derivative contracts include futures, forwards, options and swaps. ${ }^{5}$

Continuing the above example, a U.S. company exporting three million pesos of car parts to Mexico can hedge its currency risk by entering into a forward contract with a third party on the date of sale. ${ }^{6}$ At the prevailing exchange rate of three pesos per dollar, the forward contract would require the U.S. exporter to deliver three million pesos to the third party in exchange for one million dollars, in 60 days. Thus, the U.S. exporter has locked in the exchange rate of three pesos per dollar, foregoing any harm (benefit) of a weakening (strengthening) peso. 
In addition to using FXD, companies can reduce their exposure to exchange rate changes through operational decisions. In such a natural hedge, the company alters its operations to manage its currency risk. For example, a U.S. exporter could denominate its working capital loans in pesos. By establishing an accounts payable in the same peso amount as its accounts receivable, the company hedges its exposure to peso devaluations. Any foreign exchange loss on the accounts receivable would be offset by a gain on the accounts payable. Other natural hedge techniques include locating production facilities in countries where significant foreign currency sales are expected, funding foreign operations with foreign borrowings, and diversifying import and/or export markets to countries whose currencies do not closely track each other (see, e.g., Arterian 1993; Belk and Glaum 1990; Logue 1995).$^{7}$

\section{Related Literature}

Prior studies regarding U.S. MNC's management of foreign currency risk have relied primarily on survey-based data and provide evidence which is consistent with a risk-averse hedging strategy (see, e.g., Bodnar, Hayt, Marston and Smithson 1995; Collier, Davis and Longden 1990; Mathur 1982; Rodriguez 1981; Scheirer 1994). However, Belk and Glaum (1990) criticize prior research for ignoring that some companies' hedging decisions are influenced by whether and how their competitors manage currency risk. ${ }^{8}$ Research on the management of foreign currency risk is further complicated by the existence of multiple hedging techniques (e.g., natural hedges and FXD). In addition, prior studies have been hindered by the lack of public information on FXD. Houston and Mueller (1988), for example, attribute their inability to explain foreign currency hedging practices in part to the lack of information on the use of FXD and other financial instrument information.

As of June 1990, the Financial Accounting Standards Board (FASB) has required U.S. MNCs to provide information concerning FXD
(Financial Accounting Standards Board 1990). In Statement of Financial Accounting Standards (SFAS) No. 105, the FASB requires companies to disclose the notional amount of FXD. ${ }^{9}$ Per SFAS No. 105 (par. 89), notional amounts are intended to measure the company's extent of involvement in transactions that have off-balancesheet risk. ${ }^{10}$ The initial descriptive evidence indicates that while FXD usage is often substantial, the level of usage varies considerably across U.S. companies (see Goldberg, Tritschler and Godwin 1995). In particular, Goldberg et al. report that the notional amount of FXD as a percentage of total assets varies from zero to more than 60 percent.

\section{Research Objective and Method}

This study considers U.S. MNC's foreign currency risk management practices. The primary analysis seeks to explain variations in the notional amounts of foreign exchange derivatives (FXD) in relation to differences in foreign currency exposure. The FASB has indicated that such research on reporting issues currently under deliberation is critical to the standard setting process (Beresford and Johnson 1995). In addition, sensitivity analyses address a gap in the literature regarding the influence of industry membership and other interfirm differences on hedging practices. Finally, cluster analyses consider the role of multiple hedging techniques in U.S. MNC's management of currency risk.

The sample consists of large U.S. MNCs that are expected to be major users of FXD, for the 1990-1994 period. ${ }^{11}$ The sample criteria are: (1) the company is a large U.S. based multinational as measured by Forbes' list of the 100 largest U.S. MNCs, or Fortune's list of the 50 largest U.S. exporters; (2) the company disclosed FXD information in its annual report, in accordance with SFAS No. 105; (3) the company operated in a manufacturing industry (i.e., inside the 2000 to 3999 SIC code range) as reported on Standard and Poor's Compustat data tapes, for the 1990-1994 sample period; and (4) the company did not operate in the petroleum refining or related industries (i.e., in the 2900 to 2999 SIC 
code range).$^{12}$ Each company was contacted directly for its annual report, to obtain FXD information. ${ }^{13}$

With regard to the primary analysis, Goldberg et al. (1995) provide descriptive evidence of considerable variation in the use of FXD. We expect these variations in notional amounts to be explained in part by differences in foreign currency exposure. Specifically, we follow Jorion (1990) and proxy MNC's total currency exposure with the relative level of foreign sales to test the following hypothesis (in alternative form).

Ha: There is a significant and positive relationship between the use of foreign exchange derivatives and the exposure to changes in exchange rates.

The hypothesis was tested using pooled estimates of the following model.

$\ln \left(F X D A_{i t}\right)=\alpha+\beta_{1} \ln \left(F S A_{i t}\right)+\epsilon_{i t}$

where $F X D A_{\mathrm{it}}$ is the notional amount of foreign exchange derivatives (per annual report disclosure) deflated by consolidated assets for company $i$ in year $t$; and $F S A_{\mathrm{it}}$ is foreign sales (per annual report disclosure) deflated by consolidated assets for company $i$ in year $t$. A statistically significant and positive coefficient on the foreigncurrency exposure variable (FSA) is consistent with the alternative hypothesis. Log transformations were used, given evidence that the relation was nonlinear (see Dielman 1991). ${ }^{14}$ An additional advantage of such transformations is that the slope coefficient measures the elasticity of FXD use with respect to foreign currency exposure (see Hair, Anderson, Tatham and Black 1995). All variables are scaled by consolidated assets to reduce heteroscedasticity. ${ }^{15}$

Previous studies caution that U.S. MNC's hedging practices are complicated by whether and how the company's competitors manage currency risk (see Belk and Glaum 1990). In order to examine the sensitivity of the primary analysis to industry membership, equa- tion (1) was modified to include a series of dummy variables representing the two-digit SIC codes for sample industries. ${ }^{16}$ A statistically significant and positive coefficient on the foreigncurrency exposure variable (FSA) indicates that the primary results are robust to industry effects. In particular, industry effects were examined with pooled estimates of the following model.

$$
\begin{aligned}
& \ln \left(F X D A_{i t}\right)=\alpha+\beta_{1} \ln \left(F S A_{i t}\right)+\beta_{2} S I C 2_{1 i t}+ \\
& \ldots+\beta_{11} S I C 2_{10 i t}+\epsilon_{i t}
\end{aligned}
$$

where $S I C 2_{j i t}$ is coded as 1 for company $i$ in year $t$ operating in industry group $j(j=1-10$, as defined by the two-digit SIC code), and as 0 otherwise.

Similar to the industry analysis, a covariance model was used to control for differences across firms and reporting years. The dummy variables (YEAR and FIRM) allow the intercept to vary over time and across firms in pooled estimates of equation (1). Specifically, firm and year effects were examined using pooled estimates of the following covariance model.

$\ln \left(F X D A_{i t}\right)=\alpha+\beta_{1} \ln \left(F S A_{i t}\right)+\beta_{2} Y E A R_{i 1990}+$ $\ldots+\beta_{5}$ YEAR $_{\text {il993 }}+\beta_{6}$ FIRM $_{1 t}+\ldots$

$+\beta_{68}$ FIRM $_{63 t}+\epsilon_{i t}$

where $Y E A R_{i t}$ is coded as 1 in year $t$ for firm $i$ ( $t$ $=1990-1993)$ and as 0 otherwise; and FIRM $M_{i t}$ is coded as 1 for firm $i$ in year $t(i=1-63)$ and as 0 otherwise.

In addition to using FXD, companies can reduce their exposure to changes in exchange rates through the use of natural hedges. Cluster analysis was utilized to consider such multiple hedging practices. Unlike discriminant analysis, which is used when sample observations can be divided into two or more known groups, cluster analysis is used to discover natural groups within the sample (Jensen 1971). ${ }^{17}$ The subsamples formed by cluster analysis, though not necessarily the single best solution, should exhibit high (low) homogeneity within (between) clusters. For example, for companies using natural hedges, the relation expressed in equation (1) 
may be less significant than for companies where FXD use is more dominant. In addition to performing the primary analysis on these subsamples, a test of mean differences is provided.

\section{Results}

In order to capture end users of foreign exchange derivatives (FXD), the sample consists of large U.S. based MNCs operating in manufacturing industries. Table 1 summarizes the sample selection for 1990-1994. Of the initial sample of 470 observations (representing 94 firms for five years), 167 observations were omitted due to the absence of annual report information. An additional 38 observations were outside the sample industries or had fundamentally different economic characteristics from other sample observations and were omitted, leaving a final sample of 265 observations (representing 64 companies). Table 2 details the distribution of these observations by three-digit SIC code. ${ }^{18}$

Table 3 presents descriptive statistics for the 1990-1994 sample period. As seen in Panel A, the sample companies are large (mean total assets of $\$ 19,930.2$ million), though fairly diverse in size (standard deviation of $\$ 43,410.1$ million). Referring to Panel B, these companies' FXD amounts average 10.1 percent of consolidated assets. The $t$-value indicates that this dependent variable (FXDA) is statistically significant (at a .0001 level), consistent with prior evidence of significant variations in FXD use (see Goldberg et al. 1995). With regard to the independent variable (FSA), the sample companies' foreign sales represent 47.8 percent of consolidated assets (statistically significant at a .0001 level). Equation (1) incorporates this proxy of foreign currency exposure to explain variations in FXD use.

Table 4 details the ordinary least squares (OLS) regression results pertaining to equations (1) and (2). ${ }^{19}$ Referring to the primary analysis in Panel A, the model is statistically significant $(F$-value $=56.100)$. The estimated coefficient on the independent variable is also significant (at a one-sided .00005 level) and positive. This is consistent with the alternative hypothesis. In particular, the estimated coefficient indicates that U.S. MNCs increase their use of FXD by .68 percent for each one percent increase in the rela-

Table 1

Sample Selection for 1990-1994

Initial sample of large U.S. based multinational Total Number of Observations 470 companies

Companies not providing an annual report 56

Companies lacking annual report disclosure of information used in equation $(1)^{\mathrm{a}}$

Companies operating outside manufacturing industries (i.e., outside the 2000 to 3999 SIC code range)

Companies in the petroleum industry (i.e., in the 29XX

SIC code) and Dow Chemical

Total sample size

aThe model illustrated in equation (1) is:

$$
\ln \left(F X D A_{i t}\right)=\alpha+\beta_{1} \ln \left(F S A_{i t}\right)+\epsilon_{i t}
$$

where $F X D A_{\text {it }}$ is the notional amount of foreign exchange derivatives (per annual report disclosure) deflated by consolidated assets for company $i$ in year $t$; and $F S A_{\text {it }}$ is foreign sales (per annual report disclosure) deflated by consolidated assets for company $i$ in year $t$. 
Table 2

Sample Distribution by Industry Membership

\begin{tabular}{|c|c|c|}
\hline$\overline{\text { SIC Code }}$ & & Total Number of Observations \\
\hline $201 X$ & Meat products & 5 \\
\hline $204 X$ & Grain mill products & 17 \\
\hline $208 X$ & Beverages & 10 \\
\hline $211 X$ & Tobacco products & 2 \\
\hline $262 X$ & Paper mills & 4 \\
\hline $263 X$ & Paperboard mills & 1 \\
\hline $267 X$ & Converted paper & 1 \\
\hline $281 X$ & Industrial organic chemicals & 14 \\
\hline $282 X$ & Plastic materials and synthetics & 10 \\
\hline $283 X$ & Drugs & 32 \\
\hline $284 X$ & Soap, cleaners, and toilet goods & 14 \\
\hline $289 X$ & Miscellaneous chemical products & 6 \\
\hline $301 X$ & Tires and inner tubes & 5 \\
\hline $335 X$ & Nonferrous rolling and drawing & 5 \\
\hline $336 \mathrm{X}$ & Nonferrous foundries & 5 \\
\hline $342 \mathrm{X}$ & Cutlery, handtools and hardware & 5 \\
\hline $348 X$ & Ordinance and accessories & 5 \\
\hline $349 \mathrm{X}$ & Miscellaneous fabricated metal products & 2 \\
\hline $351 \mathrm{X}$ & Engines and turbines & 4 \\
\hline $352 X$ & Farm and garden machinery & 5 \\
\hline $354 X$ & Metalworking machinery and equipment & 5 \\
\hline $357 X$ & Computer and office equipment & 39 \\
\hline $362 X$ & Electrical industrial apparatus & 5 \\
\hline $363 \mathrm{X}$ & Household appliances & 10 \\
\hline $365 X$ & Household audio and video equipment & 5 \\
\hline $366 X$ & Communication equipment & 9 \\
\hline $367 X$ & Electronic components and accessories & 10 \\
\hline $371 X$ & Motor vehicles and equipment & 14 \\
\hline $372 X$ & Aircraft and parts & 6 \\
\hline $381 X$ & Search and navigation equipment & 4 \\
\hline $384 X$ & Medical instruments and supplies & 3 \\
\hline \multirow[t]{2}{*}{$386 \mathrm{X}$} & Photographic equipment and supplies & $\underline{3}$ \\
\hline & Total & $2 \overline{65}$ \\
\hline
\end{tabular}

tive level of foreign sales. Panel B of Table 4 indicates that these supportive results are not sensitive to industry membership, as the coefficient on the variable of interest (FSA) remains positive and statistically significant (at a one-sided .00005 level). ${ }^{20}$

The Table 5 results, which pertain to the equation (3) covariance analysis, indicate that the supportive results are also robust to differences associated with firms and reporting years. While including the FIRM and YEAR dummy variables improves the fit of the model, the coefficient on the foreign-currency exposure variable remains significant (at a one-sided .00005 level). ${ }^{21}$

With regard to the cluster analysis discussed in Section 3, Table 6 presents the univariate and OLS regression results on the two subsamples. As seen in Panel A, the test of mean differences indicates that the two subsamples are significantly different in their total assets (at a .0001 level) and in their FXD use relative to foreign sales (at a .001 level); however, the absolute levels of FXD use and foreign sales are not statistically significant. Specifically, companies 


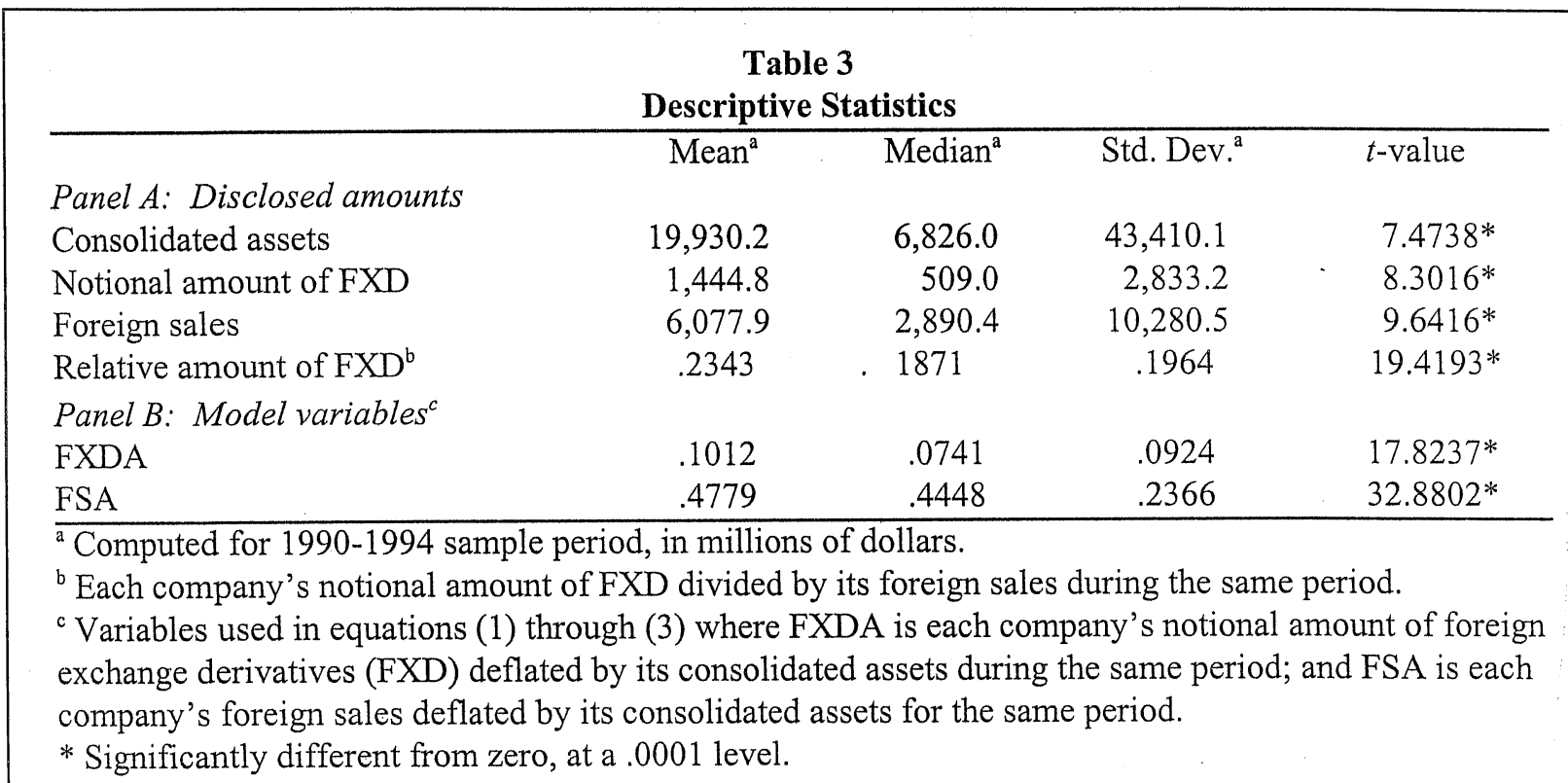

in cluster one are larger and use relatively more FXD. This is consistent with prior studies which argue that natural hedges are particularly advantageous to smaller companies, while larger companies are more likely to use derivatives (see, e.g., Arterian 1993; Block and Gallagher 1986; Booth, Smith and Stolz 1984; Nance, Smith and Smithson 1993). As seen in Panel B, the OLS regression results (which pertain to the primary analysis) are also consistent with such research. To the extent that FXD use is more dominant in larger companies, the relation expressed in equation (1) is more likely to hold. Referring to the F-tests, the model is statistically significant for cluster one, which contains the larger companies $(F$-value $=27.792)$, but not for cluster two $(F$ value $=0.569)$. Moreover, the coefficient on the foreign-currency exposure variable remains statistically significant (at a one-sided .00005 level) and positive for cluster one. In total, the Table 6 results provide preliminary insight into the use of multiple hedging techniques.

\section{Conclusion}

This study examined the use of foreign exchange derivatives (FXD) by U.S. multinational companies (MNCs). A model was developed to explain variations in the disclosed amounts of FXD in relation to differences in for- eign currency exposure. Using the SFAS No. 105 annual report disclosures of 64 U.S. MNCs for the 1990-1994 period, the results are consistent with expectations. In particular, the results indicate that FXD use is positively associated with foreign currency exposure. Moreover, we provide evidence that these results are not sensitive to industry membership or other differences across firms and reporting years. Preliminary evidence of the use of multiple hedging techniques is also provided.

\section{Suggestions for Future Research}

The losses associated with the use of derivatives have been well publicized. Less publicized are the losses that were avoided by using such financial instruments. This paper provides a more balanced perspective, and presents evidence that contributes toward a better understanding of FXD use. The Financial Accounting Standards Board has indicated that such research on issues currently under deliberation is critical to the standard setting process (Beresford and Johnson 1995). Considering the continued globalization of the business environment, there is a great need for future research into the corresponding efforts of multinationals to manage their foreign currency risk. [d] 


\begin{tabular}{|c|c|c|c|}
\hline \multicolumn{4}{|c|}{$\begin{array}{c}\text { Table } 4 \\
\text { Results of OLS Regression }\end{array}$} \\
\hline & SIC Code ${ }^{a}$ & Estimate & $t$-value \\
\hline \multicolumn{4}{|l|}{ Panel A: Primary analysis ${ }^{b}$} \\
\hline Adjusted $\mathrm{R}^{2}$ & & .1727 & \\
\hline$\alpha$ & & -2.0715 & $-21.768^{*}$ \\
\hline$\beta_{1 \mathrm{t}}$ & & 0.6753 & $7.490^{*}$ \\
\hline \multicolumn{4}{|l|}{ Panel B: Sensitivity analysis ${ }^{\mathrm{c}}$} \\
\hline Adjusted $\mathrm{R}^{2}$ & & .2221 & \\
\hline$\alpha$ & & -1.7100 & $-6.348^{*}$ \\
\hline$\beta_{1 \mathrm{t}}$ & & 0.6571 & $7.064 *$ \\
\hline$\beta_{2 t}$ & $20 \mathrm{XX}$ & -0.4615 & -1.541 \\
\hline$\beta_{3 t}$ & $21 X X$ & -0.9593 & -1.497 \\
\hline$\beta_{4 \mathrm{t}}$ & $26 X X$ & -0.6962 & -1.619 \\
\hline$\beta_{5 t}$ & $28 X X$ & -0.4134 & -1.482 \\
\hline$\beta_{6 t}$ & $30 X X$ & -1.6560 & $-3.655^{*}$ \\
\hline$\beta_{7 \mathrm{t}}$ & $33 \mathrm{XX}$ & -0.0417 & -0.112 \\
\hline$\beta_{8 t}$ & $34 X X$ & 0.2575 & 0.726 \\
\hline$\beta_{9 t}$ & $35 X X$ & -0.2725 & -0.956 \\
\hline$\beta_{10 \mathrm{t}}$ & $36 X X$ & -0.4895 & -1.659 \\
\hline$\beta_{11 t}$ & $37 \mathrm{XX}$ & -0.4204 & -1.305 \\
\hline \multicolumn{4}{|c|}{$\begin{array}{l}\text { aThe two-digit SIC codes pertain to the dummy variables in equation }(2) \text { sensitivity analysis. } \\
\text { bThe ordinary least squares (OLS) regression analysis pertains to the model expressed in } \\
\text { equation }(1) \text {, which is significant at a } .0001 \text { level }(F \text {-value }=56.100) \text { : }\end{array}$} \\
\hline \multicolumn{4}{|c|}{$\ln \left(F X D A_{i t}\right)=\alpha+\beta_{1} \ln \left(F S A_{i t}\right)+\epsilon_{i t}$} \\
\hline \multicolumn{4}{|c|}{$\begin{array}{l}\text { where } F X D A_{\mathrm{it}} \text { is the notional amount of foreign exchange derivatives deflated by consolidated } \\
\text { assets for company } i \text { in year } t \text {; and } F S A_{\mathrm{it}} \text { is foreign sales deflated by consolidated assets for } \\
\text { company } i \text { in year } t \text {. } \\
\text { 'Industry sensitivity analysis via equation (2), significant at a } .0001 \text { level }(F \text {-value }=7.853) \text { : }\end{array}$} \\
\hline \multicolumn{4}{|c|}{$\ln \left(F X D A_{i t}\right)=\alpha+\beta_{1} \ln \left(F S A_{i t}\right)+\beta_{2} S I C 2_{1 i t}+\ldots+\beta_{11} S I C 2_{10 i t}+\epsilon_{i t}$} \\
\hline \multicolumn{4}{|c|}{$\begin{array}{l}\text { where } S I C 2_{j i t} \text { is coded as } 1 \text { for company } i \text { in year } t \text { operating in industry group } j(j=1-10 \text {, as } \\
\text { defined by the two-digit SIC code), and as } 0 \text { otherwise. }\end{array}$} \\
\hline
\end{tabular}

\section{Endnotes}

1. Among the larger derivative losses in recent years are the $\$ 1.7$ billion loss in Orange County, California and the $\$ 157$ million loss at Procter and Gamble.

2. A multinational's total exposure to changing exchange rates includes the losses associated with transaction, translation and competitive effects (see, e.g., Collier and Davis 1985). Exchange rate changes subsequent to the date of a foreign currency denominated transaction result in losses at the date the fixed foreign currency amount is remitted. In contrast, exchange rate changes result in translation losses when local currency denominated financial statements of foreign operations are converted to the reporting currency. Exchange rate changes also can have a substantial effect on the profitability of both multinational and domestic companies by altering competitive conditions.

3. Per Statement of Financial Accounting Standards (SFAS) No. 52, the financial statements of "an entity with operations that are relatively self-contained and integrated within a particular country" are 
Table 5

Results of Covariance Analysis

\begin{tabular}{lrr}
\hline & Estimate $^{\mathrm{a}}$ & $t$-value \\
Adjusted R & 0.6108 & \\
$\alpha$ & -2.1401 & $-7.515^{*}$ \\
$\beta_{1 \mathrm{t}}$ & 0.5840 & $4.595^{*}$ \\
\hline
\end{tabular}

${ }^{\mathrm{a}}$ Covariance analysis results pertain to OLS estimations of the model expressed in equation (3), which is significant at a .0001 level $(F$-value $=7.183)$ :

$$
\begin{aligned}
\ln \left(F X D A_{i t}\right)=\alpha & +\beta_{1} \ln \left(F S A_{i t}\right)+\beta_{2} \text { YEAR }_{i 1990}+\ldots+\beta_{5} Y \text { YEAR }_{i 1993} \\
& +\beta_{6} \text { FIRM }_{1 t}+\ldots+\beta_{68} \text { FIRM }_{63 t}+\epsilon_{i t}
\end{aligned}
$$

where $F X D A_{i t}$ is the notional amount of foreign exchange derivatives deflated by consolidated assets for company $i$ in year $t ; F S A_{i t}$ is foreign sales deflated by consolidated assets for company $i$ in year $t ; Y E A R_{i t}$ is coded as 1 in year $t$ for firm $i(t=1990-1993)$ and as 0 otherwise; and FIRM $i t$ is coded as 1 for firm $i$ in year $t(i=1-63)$ and as 0 otherwise.

*Significant at a one-sided .00005 level.

translated using the current exchange rate (Financial Accounting Standards Board 1981, par. 6). This translation methodology has been defended from a purchasing power parity standpoint (see, e.g., Hall 1983).

4. Subsequent to Jorion (1990), other researchers considering the relationship between foreign currency exposure (defined as the sensitivity of firm value to random changes in exchange rates) and the degree of foreign involvement include Amihud (1994), Choi and Prasad (1995) and Donnelly and Sheehy (1996).

5. Futures are standardized contracts that are traded on organized exchanges such as the Chicago Board of Trade. Like futures, forward contracts require delivery of a specific quantity (e.g., quantity of foreign currency) on a specified date at a particular price. While forward contracts are not publicly traded, both types of derivatives require future transfer, which may be either favorable or unfavorable to the buyer. In contrast, options provide the buyer with the right, but not the obligation, to buy (a call option) or sell (a put option) at the specified price. Swaps, on the other hand, involve an exchange of "sets of cash flows over a period in the future" (Kolb 1996, p.
8).

6. As with any contract, the agreement must involve at least two parties. The party assuming the MNC's currency risk is usually a financial institution or another company that also is hedging or is speculating on exchange rate movements.

7. For example, Japanese automobile manufacturers with production facilities in the U.S. have benefited during the recent period of strengthening yen against the dollar. According to Logue (1995), "the greatest benefit of (such) real operating diversification has been insulation from some of the adverse competitive effects of seemingly incomprehensible currency movements" (p. 45). The currency diversification of import and/or export markets is similar to the modern portfolio theory concept of diversification -- a portfolio consisting of 15 to 20 randomly selected stocks will not have any unsystematic (firm specific) risk. The unsystematic risk is eliminated because of the less than perfect positive correlation between the randomly selected stocks in the portfolio. The only risk that remains in a fully diversified portfolio is the systematic (market) risk -- the risk that is pervasive across all firms. Similarly, such a natural hedge cannot 
Table 6

Results of Cluster Analysis

Panel A: Test of mean differences between clusters ${ }^{a}$

Cluster 1 Mean

$(\mathrm{n}=183)$

Consolidated assets

Notional amount of FXD

Foreign sales

Relative amount of $\mathrm{FXD}^{\mathrm{b}}$
$25,198.1$

$1,588.9$

$6,185.7$

.2582

\section{Cluster 2 Mean \\ $(\mathrm{n}=82)$}

$8,173.9$

$1,123.2$

$5,872.9$

.1808 $t$-value

$-21.2485^{* *}$

1.6154

0.2854

$-3.4714^{*}$

Panel B: Primary analysis on each cluster $^{c}$

Adjusted $\mathrm{R}^{2}$

\begin{tabular}{|c|c|}
\hline \multicolumn{2}{|c|}{ Cluster $1^{\mathrm{a}}$} \\
\hline $\begin{array}{r}\text { Estimate } \\
.1283\end{array}$ & $t$-value \\
\hline-2.0270 & $-12.032 * * *$ \\
\hline 0.7109 & $5.272 * * *$ \\
\hline
\end{tabular}

\begin{tabular}{cc}
\multicolumn{2}{c}{ Cluster $2^{\mathrm{a}}$} \\
\hline Estimate & $t$-value \\
-.0053 & \\
-2.1780 & $14.528^{* * *}$ \\
0.3304 & 0.754
\end{tabular}

$\beta_{\text {it }}$ $5.272 * * *$

0.3304

0.754

${ }^{a}$ Clusters were formed using both notional amount of foreign exchange derivatives (FXD) deflated by consolidated assets (i.e., FXDA), and foreign sales amount deflated by consolidated assets (i.e., FSA).

${ }^{b}$ Each company's notional amount of FXD divided by its foreign sales during the same period. 'Primary analysis pertains to OLS estimations of the model expressed in equation (1), which is significant for cluster one $(F$-value $=27.792)$ but not for cluster two $(F$-value $=0.569)$ :

$$
\ln \left(F X D A_{i t}\right)=\alpha+\beta_{1} \ln \left(F S A_{i t}\right)+\epsilon_{i t}
$$

where $F X D A_{\mathrm{it}}$ is the notional amount of FXD deflated by consolidated assets for company $i$ in year $t$; and $F S A_{\text {it }}$ is foreign sales deflated by consolidated assets for company $i$ in year $t$.

* Significantly different from zero, at a .001 level.

**Significantly different from zero, at a .0001 level.

$* * *$ Significant at a one-sided .00005 level.

eliminate all of the currency risk.

8. According to Belk and Glaum (1990), such industry effects are consistent with competitive sources of foreign currency exposure. The authors emphasize that while "this interesting point has so far been largely ignored in the literature on hedging and hedging instruments ... (it is) very much consistent with the concept of economic exposure which claims to focus on the competitive situation of the company" (p. 7). Hedging strategies also have been attributed to a manager's risk aversion, as well as to taxes, bankruptcy costs and financing costs (see, e.g., Froot, Scharfstein and Stein 1993). In addition, hedging may improve the quality of profit information by reducing exchange rate noise (DeMarzo and Duffic 1995).

9. According to Fortune (1995), "notional principal is the value of the contract upon which payments are based" (p. 26). Statement of Financial Accounting Standards (SFAS) No. 105 is part of the FASB's financial instruments project that began in 1986 . In the initial phase of this project, which is designed to improve disclosures of information about financial instruments, the FASB has also issued SFAS No. 107 (Financial Accounting Standards Board 1991) and SFAS No. 119 (Financial Accounting Standards Board 1994). These latter Standards expand disclosure requirements to include the fair value of all financial instruments. More recently, the FASB has issued a preliminary draft on a proposed Standard regarding the accounting for derivative and similar financial instruments (Financial Accounting Standards Board 1996). 
10. Off-balance-sheet risk may arise from financial instruments that are not recognized as either an asset or a liability, or may pertain to losses that exceed amounts already recognized on the balance sheet. While notional amounts measure a company's extent of involvement in offbalance-sheet transactions, recent research indicates that such data also provide risk relevant information (see McAnally 1996).

11. Recent survey evidence indicates that large U.S. based companies operating in the 2000 to 3999 SIC code range are major users of derivatives (see Bodnar, Hayt, Marston and Smithson 1995). Financial companies, in contrast, are likely to be both users and issuers of derivative contracts. Phillips (1995) reports survey evidence that suggests that a company's currency risk is an increasing function of firm size.

12. Following previous studies (see, e.g., Jorion 1990), we exclude companies operating in the 29XX SIC codes. As oil prices are commonly set in U.S. dollars, these companies' foreign currency exposure is fundamentally different from other industries in the sample. Similarly, Dow Chemical was excluded as an outlier with fundamentally different economic characteristics (please see endnote 19 for additional discussion).

13. The Standard and Poor's Compustat data tapes were used to obtain industry membership information. Other sample data was obtained from annual reports, provided directly from the sample companies. FXD data from 1992 annual reports were provided by Stephen Goldberg.

14. Model diagnostics suggested that the relationship between FXD use and foreign currency exposure may be nonlinear, for example, due to transactional cost scale economies. Mian (1996) provides evidence that companies' financial hedging activities exhibit economies of scale. After we use the log transformations depicted in equation (1), there is no evidence that the linearity assumption is violated. Recognizing that the nonlinear relation expressed in equation (1) may be affected by company size, we re-ran the primary analysis including size as an additional explanatory variable in equation (1). The results are very similar to those reported in Table 4 .

15. The need for scaling to reduce heteroscedasticity was assessed by examining the White statistic (White 1980). As an alternative to consolidated assets, consolidated sales were also used as a deflator. The results are very similar to the primary results reported in Table 4.

16. To avoid perfect multicollinearity among the dummy variables, model estimates of equation (2) excluded one two-digit SIC code variable (see Pindyck and Rubinfeld 1991). Similarly, model estimates of equation (3) excluded one firm and one year.

17. While cluster analysis is a commonly used objective method of partitioning samples, it is not a statistical inference technique -- it has strong mathematical properties but lacks a basis in probabilistic statistics (Hair, Anderson, Tatham, and Black 1995). We used the FASTCLUST procedure in SAS, which performs nonhierarchial cluster analysis based on Euclidean distance measures (SAS Institute 1985). The two clusters were formed using both the deflated amounts of foreign exchange derivatives (FXDA) and the deflated foreign sales amounts (FSA). An alternative approach to the complexity of multiple hedging techniques is to take the company's use of natural hedges as a given, and focus on the use of derivatives (see, e.g., Nance, Smith and Smithson 1993).

18. Industry sensitivity analysis was performed using equation (2). While OLS data requirements dictate model estimations at the two-digit SIC code level, the sensitivity of results to industry membership was further assessed by excluding industry groups containing the largest number of sample companies (i.e., SIC codes $283 \mathrm{X}$ and $357 \mathrm{X})$. The results excluding such sample observations are very similar to the primary results reported in Table 4 . 
19. With regard to model assessment issues, diagnostics used to assess OLS error-term assumptions include residual and normal probability plots, the Shapiro-Wilk test for nonnormality and the White test for heteroscedasticity. In addition, diagnostics available from the INFLUENCE option in the SAS regression procedure were used to consider the impact of outliers. In total, the model diagnostics suggest that departures from OLS assumptions do not hinder tests of the hypothesis.

20. As seen in Table 4, the coefficient on the variable representing companies operating in the 30XX SIC codes is also significant (at a .0001 level). To further examine industry effects, equation (2) was reestimated after omitting the foreigncurrency exposure variable (FSA). This modified model is significant ( $F$-value $=$ 3.060 ), which suggests that industry membership does contribute to explaining variations in FXD use. However, a partial F-test indicates that the full model given in equation (2) is significantly better ( $F$-value $=24.947)$ than this reduced model in explaining FXD use.

21. In order to jointly test the FIRM and YEAR variables, equation (3) was reestimated after excluding the foreigncurrency exposure variable (FSA). This modified model is significant $(F$-value $=$ 6.329), indicating that the variation in FXD use can be explained in part by timedependent and firm-dependent effects. However, a partial F-test indicates that the full model given in equation (3) is significantly better $(F$-value $=10.611)$ than this reduced model in explaining FXD use.

\section{References}

1. Amihud, Y., "Exchange Rates and the Valuation of Equity Shares," in Y. Amihud and R. M. Levich (eds.) Exchange Rates and Corporate Performance, New York: Irwin, pp. 49-59, 1994.

2. Arterian, S., "Smooth Sailing Through Currency Swings," CFO, Vol. 9, No. 1, pp. 53-55, 1993.

3. Belk, P. and M. Glaum, "The Management of Foreign Exchange Risk in U.K. Multinationals: An Empirical Investigation," Accounting and Business Research, Vol. 21, No. 18, pp. 3-13, 1990.

4. Beresford, D.R. and L.T. Johnson, "Interactions between the FASB and the Academic Community," Accounting Horizons, Vol. 9, No. 4, pp. 108-117, 1995.

5. Block, S. B. and T.J. Gallagher, "The Use of Interest Rate Futures and Options by Corporate Financial Managers," Financial Management, Vol. 15, No. 3, pp. 73-78, 1986.

6. Bodnar, G.M., Hayt, G.S., Marston, R.C. and C.W. Smithson, "Wharton Survey of Derivatives Usage by U.S. Non-financial Firms," Financial Management, Vol. 24, No. 2, pp. 104-114, 1995.

7. Booth, J.R., Smith, R.L. and R.W. Stolz, "The Use of Interest Futures by Financial Institutions," Journal of Bank Research, Vol. 15, pp. 15-20, 1984.

8. Choi, J.J. and A.M. Prasad, "Exchange Risk Sensitivity and Its Determinants: A Firm and Industry Analysis of U.S. Multinationals," Financial Management, Vol. 24, No. 3, pp. 77-88, 1995.

9. Collier, P. and E. Davis, "The Management of Currency Transaction Risk by U.K. Multi-national Companies," $A c$ counting and Business Research, Vol. 15, No. 60, pp. 327-334, 1990.

10. Collier, P., Davis, E., Coates, J. and S. Longden, "The Management of Currency Risk: Case Studies of U.S. and U.K. Multinationals," Accounting and Business Research, Vol. 20, No. 79, pp. 206-210, 1990.

11. DeMarzo, P.M. and D. Duffic, "Corporate Incentives for Hedging and Hedge Accounting," The Review of Financial Studies, Vol. 8, No. 3, pp. 743-771, 1995.

12. Dielman, T. E., Applied Regression Analysis for Business and Economics, Boston: PWS, 1991.

13. Donnelly, R. and E. Sheehy, "The Share 
Price Reaction of U.K. Exporters to Exchange Rate Movements: An Empirical Study," Journal of International Business Studies, Vol. 27, No. 1, pp. 157-165, 1996.

14. Dufey, G., "Corporate Finance and Exchange Rate Variations," Financial Management, Vol. 1, No. 2, pp. 51-57, 1972.

15. Financial Accounting Standards Board, Accounting for Derivative and Similar Financial Instruments and for Hedging Activities, Norwalk, Connecticut: Author, 1996.

16. Financial Accounting Standards Board, Disclosure about Derivative Financial Instruments and Fair Value of Financial Instruments, Norwalk, Connecticut: Author, 1994.

17. Financial Accounting Standards Board, Disclosures about Fair Value of Financial Instruments, Norwalk, Connecticut: Author, 1991.

18. Financial Accounting Standards Board, Disclosure of Information about Financial Instruments with Off-Balance-Sheet Risk and Financial Instruments with Concentrations of Credit Risk, Norwalk, Connecticut: Author, 1990.

19. Financial Accounting Standards Board, Foreign Currency Translation, Norwalk, Connecticut: Author, 1981.

20. Financial Instruments Task Force, Derivatives: Current Accounting and Auditing Literature, New York: American Institute of Certified Public Accountants, 1994.

21. Fortune, P., "Stocks, Bonds, Options, Futures and Portfolio Insurance: A Rose by any other Name," New England Economic Review, pp. 25-46, 1995.

22. Froot, K.A., Scharfstein, D.S. and J.C. Stein, "Risk Management: Coordinating Corporate Investment and Financing Policies," Journal of Finance, Vol. 48, No. 5, pp. 1629-1658, 1993.

23. Goldberg, S., Tritschler, C. and J. Godwin, "Financial Reporting for Foreign Exchange Derivatives," Accounting Horizons, Vol. 9, No. 2, pp. 1-16, 1995.

24. Hair, J.F., Anderson, R.E., Tatham, R.L. and W.C. Black, Multivariate Data Analy- sis, Englewood Cliffs, New Jersey: Prentice Hall, 1995.

25. Hall, T.W., "Inflation and Rates of Exchange: Support for SFAS No. 52," Journal of Accounting, Auditing and Finance, Vol. 6, No. 4, pp. 299-313, 1983.

26. Houston, C.D. and G.G. Mueller, "Foreign Exchange Rate Hedging and SFAS No. 52: Relatives or Strangers?," Accounting Horizons, Vol. 2, No. 4, pp. 50-57, 1988.

27. Jensen, R.E., "A Cluster Analysis of Financial Performance of Selected Business Firms," The Accounting Review, Vol. 46, No. 1, pp. 36-56, 1971.

28. Jorion, P., "The Exchange-Rate Exposure of U.S. Multinationals," Journal of Business, Vol. 63, No. 3, pp. 331-345, 1990.

29. Kolb, R., Financial Derivatives, Cambridge, Massachusetts: Blackwell Publishers, 1996.

30. Logue, D., "When Theory Fails: Globalization as a Response to the (Hostile) Market for Foreign Exchange," Journal of Applied Corporate Finance, Vol. 8, No. 3, pp. 39-48, 1995.

31. Mathur, I., "Managing Foreign Exchange Risk Profitably," Columbia Journal of World Business, Vol. 17, No. 4, pp. 2330, 1982.

32. McAnally, M.L., "Banks, Risk and FAS 105 Disclosures," Journal of Accounting, Auditing and Finance, Vol. 11, No. 3, 1996.

33. Mian, S.L., "Evidence on Corporate Hedging Policy," Journal of Financial and Quantitative Analysis, Vol. 31, No. 3, pp. 419-439, 1996.

34. Nance, D.R., Smith, C.W. and C.W. Smithson, "On the Determinants of Corporate Hedging," Journal of Finance, Vol. 48, No. 1, pp. 267-284, 1993.

35. Pare, T., "Learning to Live with Derivatives," Fortune, Vol. 130, No. 2, pp. 106116, 1994.

36. Phillips, A.L., "1995 Derivative Practices and Instruments Survey," Financial Management, Vol. 24, No. 2, pp. 115-125, 1995. 
37. Pindyck, R.S. and D.L. Rubinfeld, Econometric Models and Economic Forecasts, New York: McGraw-Hill, 1991.

38. Rodriguez, R., "Corporate Exchange Risk Management: Theme and Aberrations," The Journal of Finance, Vol. 36, No. 2, pp. 427-442, 1981.

39. SAS Institute, SAS User's Guide: Statistics Version 5, Cary, North Carolina: Author, 1985.

40. Scheirer, L., "Going Global: What Does it Mean for Foreign Exchange Risk Management?" TMA Journal, Vol. 14, No. 3, pp. 54-58, 1994.

41. Whitaker, M.B., "Strategic Management of Foreign Exchange Exposure in an International Firm," in Y. Amihud and R.M. Levich (eds.) Exchange Rates and Corporate Performance, New York: Irwin, pp. 247-251, 1994.

42. White, H., "A Heteroskedasticityconsistent Covariance Matrix Estimator and a Direct Test for Heteroskedasticity," Econometrica, Vol. 48, No. 4, pp. 817838, 1980. 